\title{
DEVELOP A STRATEGIC PLANNING MODEL FOR PLANNING IN IRANIAN UNIVERSITIES
}

\author{
Reza Mahdi \\ Asst. Prof., Institute for Social and Cultural Studies (ISCS), Tehran, Iran \\ Mahdi@ISCS.ac.ir
}

\begin{abstract}
Strategic planning for universities is a necessity. Using the strategic planning process, it is possible to develop appropriate and effective solutions and initiatives for the universities growth and development and confrontation to the external environment in national and universal dimensions. Despite the history and valuable results of strategic planning for commercial and trading organizations and business sector, the application of this planning for universities is less historic and its results has not been successful and satisfactory. In the paper, an interactive indicator-oriented 9-step model was developed for strategic planning in Iranian state universities of technology. The model is yield of the documents study, quality analysis of performed studies and content analysis of existing strategic plans documents. In this model, it is considered to the reasons for the failure in strategic planning for universities and the main differences between the commercial and university models. The model with focus on key performance indicators and interactive of past, present and future, is nine steps continuous process: Step 1: Design, installation and promotion of USP structure, Step 2: Mission review and determining and design of the KPIs, Step 3: Data gathering and study and analysis of internal status, Step 4: Data gathering and study and analysis of external status, Step 5: Design and codify the development vision and goals, Step 6: Design and codify the university development strategies, Step 7: Design the development solutions and operational actions, Step 8: Preparing the development execution plan documents, Step 9: Monitoring and evaluate programs status and progress.
\end{abstract}

Keywords: Strategic Planning, University Development, Interactive Model, Key Performance Indicators $(\mathrm{KPI})$.

\section{INTRODUCTION}

Strategy and the strategic thought is future-seeing approach. The reasons for the differences between man, institutions, universities, governments and nations contribute to the selection of premier and more effective strategies for the oncoming time horizon (Mintzberg, 2002). The theoretical fundamentals of the strategic planning were founded at Harvard Business Review in years 1954-1961 and their corresponding concepts were studied seriously since 1960s by theoreticians like Chandler as determination of goals, identification activities and allocation of the required sources in subject to goals (Chandler, 1962). Thereafter, the strategy concept was developed by other scientists such as Ansoff and Mintzberg (Ansoff, 1965) and (Gluek, 1980). The background and theoretical and executive history of the strategic planning in commercial extents is more than a half century. Unlike the commercial organizations, the strategic planning for scientific and academic 
organizations is less historic and the obtained results are less desirable and satisfactory (Rowley et al., 1997). One of the main reasons for the failure in strategic planning for universities contributes to the differences between the commercial and academic models (Rowley et al., 1997). In most of the university strategic planning cases, the commercial and trading models were applied for the strategic planning. The first experiences of academic strategic planning return to year 1959. In this year, 25 academic planners established the society for college and university planning (SCUP) at MIT. The staff organized 300 academic planners (Holmes, 1985). Afterwards, the strategic planning new age started since mid-1970s to mid-1980s. Meantime, the higher education encountered population, economic and technological problems and challenges. Meanwhile, the educational costs increased and the governmental supports declined. Because of the necessity, the strategic planning concept was entered to the higher education (Dooris, 2002). In 1983, the academic strategy book was written by Keller in order to get the academic environments and managers acquainted with strategic planning concepts (Keller, 1983). Since 1980s to early 1990s, application of strategic planning for higher education increased. After 1990s and in early years of the $21^{\text {st }}$ century, the strategic planning reached to a remarkable position. Nowadays, according to the increase in the necessity and emergence of serious challenges, the strategic planning for the academic systems is continued more power and centrality.

In this paper, based on the documental study, quality analysis of performed studies and existing pathologies and experiments (Mahdi, 2009), firstly the necessity for the using strategic planning for Iranian universities was described. Then, the main differences between the commercial and academic situations and spaces were stated. Finally, an indicator-oriented interactive model (IIM) was developed for the strategic planning in the Iranian state universities.

\section{RESEARCH METHOD}

The methodology of this research is a combination of systematic approach, documents study, meta-analysis results of other studies and content analysis of strategic process and plans documents of the some Iranian valid universities. The scientific resources and books and valid articles in university system strategic planning field is studied and compared. Also, strategic planning process and strategic plans documents in Iranian valid universities and institutions like SBU, AUT, PNU, IROST, technology field of MSRT, is studied and been content analysis. So, the document of Iranian Hi-Tech development plans like Nanotechnology development plan, Biotechnology development plan, ICT development plan, is studied and analyzed.

\section{THE DEVELOPED MODEL}

The purposeful investigations done to select an efficient model for university strategic planning show there is not reliable executive model in this field. For example, Yamani introduced some models like Keller, Cleland \& King, Barker, and Smith in the book of "university development planning" and he has developed a model in this book (Yamani, 2003). These models have provided adequate fields for contemplating about the problems and dimensions in the university system and required fields for university strategic planning. However, it is impossible to make applied strategic plans for universities. Also, for the most executive models developed by Aggarwal (1987), Bollinger (1990), Rowley and others (1997) for university strategic planning, there are serious problems in encountering the Iranian university system. As the application of these models in the university system requires master experts which identification and applying such individuals for a strategic planning process is practically difficult. In addition, the model that developed by Bryson (Bryson, 1995) for strategic planning in governmental and non-governmental organizations which most of the academic strategic plans in Iran are utilizing just provides a general framework for the strategic planning. Thus, documental studies and purposeful investigations done to select an applied model for academic strategic planning show that despite the production of affluent and reliable knowledge and literature in this field (know-why knowledge), such a model has not been developed for the academic system strategic management (know-how knowledge) yet. Yamani declared by scientific research that there is no successful experience of university strategic planning in Iran (Yamani, 2003). In the past semi-century, there were valuable experiences about strategic planning in Iranian state universities such as Payam-e-Noor, Shahid Beheshti, Amirkabir universities, Iranian research organization on science and technology (IROST) and etc. The revision of documents and strategic plans documents in these universities indicate that the strategic planning model in these universities has significant similarities and differences, and on the other hand, none of the used models for these universities are completely applicable in the other Iranian university and academic environments.

In this paper, a strategic planning model was developed for the Iranian state universities according to the Ackoff planning model (1981), Rowley and coauthors planning model (1997), the planning models introduced and developed by Yamani (2003) and the used models in some Iranian and universal universities. This model is nominated as "indicator-oriented Interactive Model (IIM)". The term 'interactive' refers to the 
classifying of planning types done by Ackoff best of which was nominated as 'interactive planning' (Ackoff, 1981). In the Interactive planning, the laziness present in the reactive past-based planning model, the stationary present in the inactive present-based planning model and the assertiveness present in the proactive future-based planning model does not exist. Interactive planning model considers the past, present and future as inseparable aspects of a chaos which must be planned and reminds the important principle that the development is impossible without stable consideration to the past, present and future (Ackoff, 1981). The Interactive planning model is in pursuit of designing desirable future and inventing its creation ways considering the previous trend and present facilities.

Also, the term 'interactive-oriented' is a kind of learning from thought and experience that belonged to Yamani (2003) and Rowley and others (1997) in university strategic planning. The principal base of the university strategic planning model developed by Rowley and coauthors is key performance indicators (KPI). Documents review, achievements and advantages and disadvantages of university strategic planning in Iran shows that the application of the Rowley and coauthors (1997) model is an appropriate function to support advantages and descend some disadvantages of the used models for university strategic planning. The indicator-oriented interactive strategic planning model (IIM) is based on two main principles:

i) To be Interactive strategic planning in university system,

ii) Selection, design and development of key performance indicators (KPI) for university system

Therefore, the core of university strategic planning (USP) is selection, design and development of KPIs and determining and explaining of university system status on past, present and future periods with KPIs-oriented (fig 1).

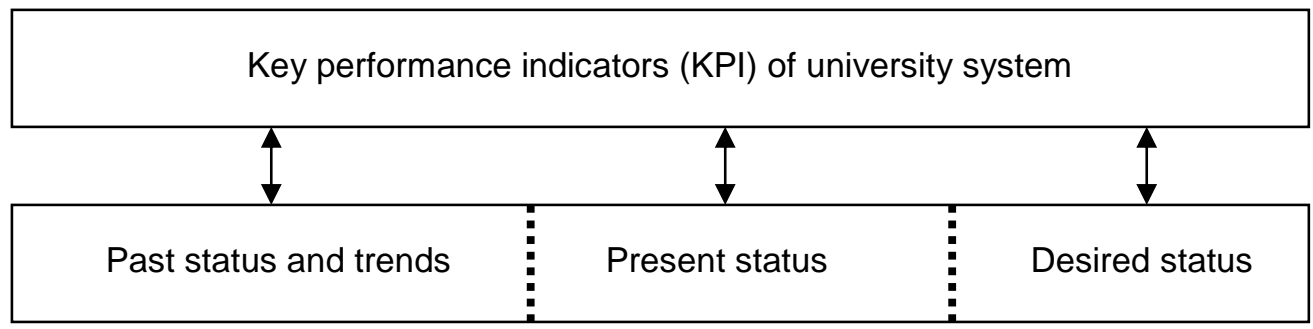

Fig1: Relations of Indicators and Periods

The steps of developed strategic planning model are as follows (Fig 2):

Step 1: Design, installation and promotion of USP structure

The organizational structure of USP is included hierarchy decision-making operational groups, designed and installed based on university organizational structure. These groups is included central USP council, educational strategic planning committee, research strategic planning committee, technology strategic planning committee, cultural and scholarship strategic planning committee, finance and services strategic planning committee. Also, colleges and unites affiliated to the university must have strategic planning special teams. It is obvious that the compounds and relations of the central council, committees and teams is dependent to organizational culture and status of the university and it can' $n$ and must not forecast them.

Step 2: Mission review and determining and design of KPIs

The university's KPIs are indicators and guides that they design, explain and draw the university system status in dimensions of educational, research, technology, scholarship, cultural, financial, services, human resources, physical resources, and etc in appropriate levels in special missions of university system direction.

The number and variation of the KPIs is depend to type, size, dimensions and main priorities of university and the quality of using strategic planning. The number of KPIs can be between 10 to 300 indicators (Rowley et al., 1997). The number and quality of KPls is determined by university decision-makers, based on organizational structure of USP. Also, the KPIs, during strategic planning process is flexible and they can be changed. Based on university organizational structure, the KPIs must be design and be select. The other point is that the KPIs must be separate and operational be define, and university stakeholders and strategic planning process participators must agree on selection and definitions of the KPIs.

Step 3: Data gathering and study and analysis of internal status

In this step, based on the determined and defined KPIs in before step, required data and information is 
gathered and organized on a given period. On existing information and the KPIs, university internal status must study and analyze in hierarchy organizational structure of USP. The main results and achievements of internal analysis is recognition and priority-determining of strengths and weaknesses of university, based on the determined KPIs. It is obvious that based on internal analysis and gathered data, planners can review and revise the KPIs, if necessary.

Fig 2: University System Strategic planning Steps:

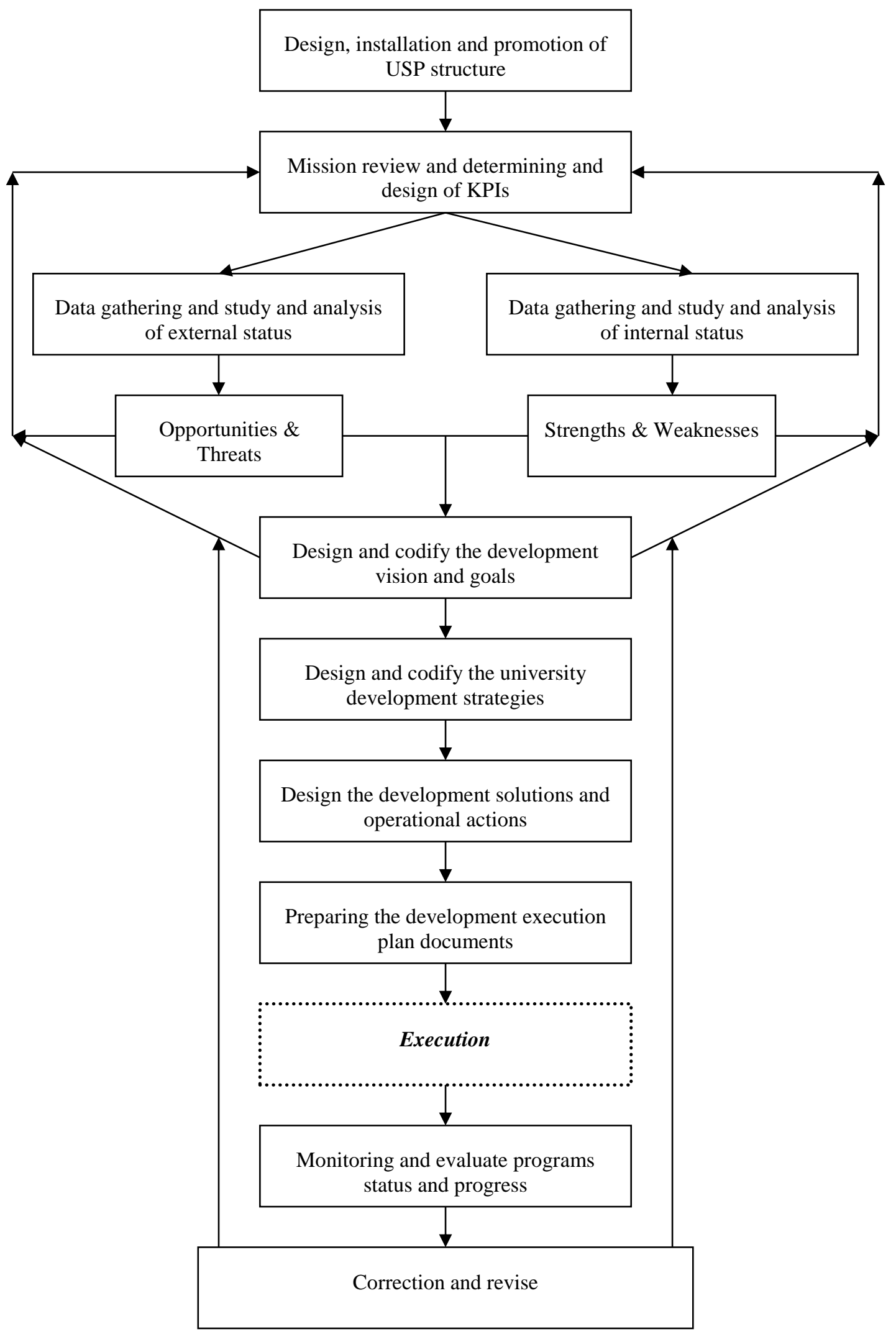


Step 4: Data gathering and study and analysis of external status

In this step like step 3, based on the determined and defined KPIs, required data and information is gathered and organized on a given period. On existing information and the KPIs, university external status must study and analyze in hierarchy organizational structure of USP. The main results and achievements of external analysis is recognition and priority-determining of opportunities and threats of university, based on the determined KPIs. It is obvious that planners can review and revise the KPIs, if necessary, based on external analysis and gathered data.

\section{Step 5: Design and codify the development vision and goals}

In this step, in hierarchy of planning organization, desired future of university system (vision and short-term, mid-term and long-term goals) is designed and approved based on the KPIs and strengths, weaknesses, opportunities and threats (SWOT). According to academic spaces organizational culture and necessity to academic republic, the desired future of university system must draw in form of unanimity and satiation. Also, university goals must transparently and operational determine. It is possible that the KPls revised during goal setting and future making.

\section{Step 6: Design and codify the university development strategies}

In this step, in hierarchy of strategic planning organization, based on the KPIs, strengths, weaknesses, opportunities and threats (SWOT) and approved goals, university development strategies is designed and codified (Fred, 1997). The designed strategies must have be relation and proportion with the KPIs, strengths, weaknesses, opportunities and threats (SWOT) and approved goals. Without referring to a given goal and a strength, weakness, opportunity and threat, the strategies can' $\mathrm{n}$ be tool and factor for university development.

\section{Step 7: Design the development solutions and operational actions}

In this step, in hierarchy of strategic planning organization, based on the designed strategies in before step, the university development solutions and operational actions is designed and then, there priority is determined. The solutions and operational actions must have be relation with approved goals and codified strategies (Rowley et al., 1997).

\section{Step 8: Preparing the development execution plan documents}

In this step, based on the results and outputs of before step (step 7), university plan and budget is prepared in separation of existing units and centers in university organizational structure. The university development execution plan document/documents must have be timing, budgeting, execution methods, supervising criteria, reporting hierarchy and etc. In the strategic planning process, a comprehensive document is prepared for total university. Follower the comprehensive document, subdocuments is prepared for each of education, research, technology, services, scholarship, cultural fields. Also, based on the comprehensive document, subdocuments is prepared and approved for each of colleges, unites and centers of related to the university.

\section{Step 9: Monitoring and evaluate programs status and progress}

The one of essential phase in university strategic planning is the sub-process of monitoring and evaluation of programs status and progress (Ackoff, 1981). Based on monitoring and evaluation process, the programs and plans must be review and be updated. The experience of using strategic planning in commercial and academic spaces show that any plan, although exact and complete, without monitoring, evaluation and supporting execution period, can't lead to effectiveness results and sued goals of designers, policy-makers and executives.

\section{CONCLUSION}

Based on the criteria of development of universities functions, emergence of academic entrepreneurship, continuous change in requirements, the necessity for productivity and accountability, the universities necessity to becoming knowledge-based, oncoming challenges of higher education, trustee board governance system, and necessity for quality assurance in the higher education and universities, the using strategic planning for universities is a necessity. Using strategic planning process can develop effectiveness solutions and initiatives for universities development. In spite of the oldness and valuable achievements of strategic planning for commercial organizations, this planning in universities have less precedent and the obtained results are little satisfactory.

In this paper, based on the systems approach, the documents study, meta-analysis results of other studies and content analysis of the strategic plans documents of some Iranian state universities, an interactive 
indicator-oriented model was developed for strategic planning in Iranian state universities. The model with focus on key performance indicators and interactive of past, present and future, is nine steps continuous process:

Step 1: Design, installation and promotion of USP structure, Step 2: Mission review and determining and design of the KPIs, Step 3: Data gathering and study and analysis of internal status, Step 4: Data gathering and study and analysis of external status, Step 5: Design and codify the development vision and goals, Step 6: Design and codify the university development strategies, Step 7: Design the development solutions and operational actions, Step 8: Preparing the development execution plan documents, Step 9: Monitoring and evaluate programs status and progress.

Using the developed model in this article, most Iranian state universities and research institutions can apply strategic planning process with minimum complexity. The universities using strategic planning process will be benefiting from strategic management results.

\section{REFERENCE LIST}

Ackoff L. R. (1981), Creating the corporate future: plan or be planned for, Wiley, John \& Sons Pub.

Aggarwal R. (1987) Systematic strategic planning at a state university, Innovative higher education, 11(2), p: $122-136$.

Ansoff H. (1965), Corporate Strategy, McGraw-Hill, New York.

Arasteh H. R. (2001), Management in Iran's state universities: The challenges and shortages, Journal of research and planning on higher education, No 21-22, p: 41-69 (in Persian).

Azargashb E., H. Araste, Z. Sabbaghian and J. Towfighi (2007), Investigation of trustees boards functions and there role on indepency of Iran's state universitis, Journal of development steps in medical education, period $4^{\text {th }}$, No 1 , p: $19-29$ (in Persian).

Bollinger J.G. (1990), Strategic planning in a academic environment, Engineering Education, 80, p: 19-22.

Brennan J. and Shah T. (2000), Managing Quality in Higher Education., OECD, SRHE, the Open U. press.

Brubacher, J.S. (1977), On the philosophy of H.E., Jossey-Bass, London.

Bryson, J.M., (1995), Strategic planning for public and nonprofit organizations, San Francisco, Jossey-Bas.

Chandler A. (1962), Strategy and Structure, MIT press.

Damme, V.D. (2000), European Approaches to Quality Assurance: Models, Characteristics and Challenges, South African Journal of Higher Education, Vol. 14, No. 2, p: 11-20.

Donaldson, J. (1995), European Pilot Projects for Evaluating Quality in Higher Education: Guidelines for Participating Institutions, Higher Education in Europe, Vol. 20, No. 1-2, p: 116-132.

Dooris M. (2002), Two Decades of Strategic Planning, Planning for Higher Education, 31(2), p: 26-32.

Etzkowitz, H. (2001), The Second Academic Revolution and the Rise of Entrepreneurial Science, IEEE Technology and Society, 22: 18-29.

Etzkowitz H. \& L. Leydesdorff (2000), The dynamics of innovation: from National Systems and "Mode 2" to a Triple Helix of university, industry, government relations, Research Policy $29: 109-123$

Frazer, M. (2005), Is the Four-stage Model of Quality Evaluation Appropriate, Paper Presented in first Athens International Conference: Demonstrating Quality in Higher Education, May 2005. Athens, Greece.

Fred, R. David (1997), Strategic Management, Prentice Hall-Gale.

Gardner D. P. (1995), Managing transitions in a time of acute ordering, Trusteeship, 3 (4), p: 9-16.

Gibbons M. (1994), The new production knowledge: The dynamics of science \& research in contemporary societies, London, Sage.

Gluek, W. F. (1980), Business Policy and Strategic Management, McGraw-Hill. 
Harman, G. (1998), The Management of Quality Assurance: A review of International Practice, Higher Education Quarterly, Vol.52, No.4, p: 344-365.

Hirsch W.Z. \& Weber L. E. (1999), Challenges Facing Higher education at the Millennium, California U. and Geneva U., Emerald Group Pub. Limited.

Holmes J. (1985), 20/20 Planning, Ann Arbor, Society for College and University Planning.

Ireland R.D. \& M.A. Hitt (1992), Mission statements, challenge and recommendations for development, Business Horizons, May \& June, p: 35-41.

Keller G. (1983), Academic strategy, Baltimore, Johns Hopkins U. press.

Lovett C. (1996), How to start restructuring our colleges, planning in H.E., 24 (3), p: 19-21.

Madi, R. (2009), Evaluating science production strategies in the Iranian technical-engineering group, Ph.D. thesis, Tehran, SBU. (in Persian).

Mintzberg H. (2002), Strategy Formulation, Vol. 1, schools of Thought, JAI press.

Nelson, R.R. (1993), National Innovation Systems: A Comparative Analysis. New York, Oxford U. press.

Sije Peter V. D. (2005), New Concepts for Academic Entrepreneurship, Twente U., Netherlands.

Ramezani R. (2002), The current problems of universities and Iran's scientific development system, Journal of research and planning on higher education, No 3, year $8^{\text {th }}$, p: 37-62 (in Persian).

Rowley D. J., Lujan H.D. and Dolence M.G. (1997), Strategic Change in Colleges and Universities: Planning to Survive and Prosper, Jossey-Bass, John Wiley \& Son Inc.

Smeby, J. C. \& Stensaker B. (1999), National Quality Assessment Systems in the Nordic Countries: Developing an Balance between External and Internal Needs, Higher Education Policy, Vol. 12, No. 1, p: $4-15$.

Srikanthan G. \& Dalrymple J. (2001), A synthesis of a quality management model for education in universities, Intn'l Journal of Educational Management, Vol. 18, issue: 4.

Steeples D.W. (1990), Managing change in higher education, new directions for H.E. , No. 71, San Francisco, Jossey-Base.

Tully S. (1995), Finally, colleges start to cut their crazy costs, Fortune, May, p: 111-115.

Viale R. \& B. Ghiglione (1998), The triple Helix Model: A tool for the study of European regional socioeconomic systems, The IPTS report, 29.

Wahlen, S. (1998), Is There a Scandinavian Model of Evaluation of Higher Education, Higher Education Management, Vol. 10, No. 3, p: 27-41.

Woodhouse, D. (1996), Quality Assurance: International Trends, Pre-Occupations and Features, Assessment and Evaluation in H.E., Vol. 21, No. 4, p: 348-357.

Wang C. L., Ahmed P. K. (2003), Structure \& Structural Dimensions For Knowledge-Based Organizations, Measuring Business Excellence, Vo.17, Issue 1:12.

Yamani D. S. M. (2003), Development planning of university system: The theories and experiences, Tehran, SBU press, (in Persian). 